\title{
Anatomical description of retromolar foramina in dry human mandibles: incidence, morphometry, and topography
}

\author{
Descrição anatômica de forames retromolares em mandíbulas humanas maceradas: incidência, morfo- \\ metria e topografia
}

Luiz Felipe PALMA ${ }^{1}$

(iD) ORCID iD 0000-0002-4472-6941

Leonardo Augusto LOMBARDI²

(iD) ORCID iD 0000-0002-9735-8804

\section{ABSTRACT}

\section{Objective}

To carry out morphometric, topographic, incidence analysis of retromolar foramina in dry adult human mandibles, and relate the findings to Dental practice.

\section{Methods}

265 mandibles were evaluated simultaneously by two researchers. With the aid of metal wires, each retromolar foramen was classified regarding diameter. Foramina with a diameter smaller than $0.5 \mathrm{~mm}$ were not taken into account.

\section{Results}

Retromolar foramina were observed in $23.4 \%$ of cases, with a higher bilateral incidence (with distinction of both antimeres), and up to 4 of them located in the same mandible. Furthermore, most foramina had a diameter between 0.5 and $1 \mathrm{~mm}$.

\section{Conclusion}

The retromolar foramina are clinically relevant findings and should never be underestimated by clinicians.

Indexing terms: Anatomy. Mandible. Oral surgery.

\section{RESUMO}

\section{Objetivo}

Realizar análises morfométrica, topográfica e de incidência de forames retromolares em mandíbulas humanas maceradas de adultos, correlacionando os achados com a prática clínica odontológica.

\section{Métodos}

265 mandíbulas foram avaliadas simultaneamente por dois observadores. Com o auxílio de fios de metal, cada forame retromolar foi classificado quanto ao diâmetro. Forames inferiores a $0.5 \mathrm{~mm}$ não foram contabilizados.

\section{Resultados}

Observaram-se forames retromolares em $23.4 \%$ dos casos, com maior incidência bilateral (com distinção dos antímeros) e podendo ocorrer em número de até 4 em uma mesma peça anatômica. Além do mais, a grande maioria apresentou diâmetro entre 0.5 e $1 \mathrm{~mm}$.

\section{Conclusão}

Os forames retromolares são achados consistentes e clinicamente relevantes, não devendo ser subestimados pelos clínicos.

Termos de indexação: Anatomia. Mandíbula. Cirurgia bucal.

\section{INTRODUCTION}

The triangular-shaped region previously delimited by the mandibular third molar tooth, medially by the temporal crest, and laterally by the anterior margin of the mandibular ramus is denominated the retromolar trigone [1-3]. The retromolar foramen (RF), generally situated in the alveolar and central portion of the retromolar trigone

\footnotetext{
${ }^{1}$ Universidade Federal de São Paulo, Divisão de Radioterapia, Departamento de Diagnóstico por Imagem. Rua Napoleão de Barros, 715, 04024-002, São Paulo, SP, Brasil. Correspondência para / Correspondence to: LF PALMA. E-mail: <luizfelipep@hotmail.com>

${ }^{2}$ Universidade Federal de São Paulo, Departamento de Morfologia e Genética. São Paulo, SP, Brasil.

$\checkmark v \boldsymbol{V}$

Como citar este artigo / How to cite this article

Palma LF, Lombardi LA. Anatomical description of retromolar foramina in dry human mandibles: incidence, morphometry, and topography. RGO, Rev Gaúch Odontol. 2018;66(2):00-00. http://dx.doi.org/10.1590/1981-863720180001000013378
} 
consists of the external opening of a canal localized within the mandibular body, denominated the retromolar canal (RC) $[4,5]$. Although it has been elucidated in the literature, it is normally neglected by surgeons, in addition to not being mentioned in books on Dentistry or in the official Anatomic Terminology [6,7]. Moreover, conventional panoramic radiographs are also not capable of showing these foramina and canals satisfactorily $[3,8,9]$.

Some studies have sought to evaluate the prevalence, topographical and morphometric characteristics, and neurovascular content of the RF and RC, however, with incomplete definition $[10,11]$. The branches of the inferior alveolar artery and nerve are believed to leave the mandibular canal through them (RF and RC) and reach the jugal and retromolar mucosae, vestibular gingiva of mandibular molars and premolars [3], and the buccinator and temporal muscles $[7,8]$. Studies have also suggested that before the branches of the inferior alveolar nerve penetrate into the mandibular foramen, they may assume a descendant trajectory and reach the mandibular canal through the RF [6] or that the branches of the buccal nerve also enter into the mandibular canal through the RF and RC [9].

Surgical procedures such as extraction, orthognathic surgery, implant placement, mandibular reconstruction, biopsies $[2,5]$, and bone tissue donation for grafts [4,12], are extremely common in the retromolar region, and thus, knowledge about the structures and anatomic variations present there are of great interest to surgeons.

According to the controversies and limited information present in the literature, the aim of this study was to analyze the morphometry, topography and incidence of RFs in macerated human mandibles.

\section{METHODS}

\section{Sample origin and selection}

A total of 265 macerated human mandibles, belonging to the Cranium Museum ("Museu de Crânios") of the Federal University of São Paulo (São Paulo, Brazil) were used, without classification relative to gender or ethnicity. The anatomic parts presented the retromolar regions completely preserved, and by means of rapid visual evaluation of dentition and craniofacial characteristics (sutures, weight, size) extremely young individuals were excluded from the analyses.

\section{Morphologic analysis}

The mandibles were visually evaluated simultaneously by two anatomist researchers, who always obtained complete agreement between them.

Initially, the total number of RFs per mandible were counted, with distinction between the antimeres. In sequence, and with the help of metal wires 0.5 and $1 \mathrm{~mm}$ in diameter (Figure 1), each RF observed was classified according to the caliber (Figures 2 and 3). All the data were tabulated, but foramina with dimensions smaller than 0.5 $\mathrm{mm}$ were not considered.

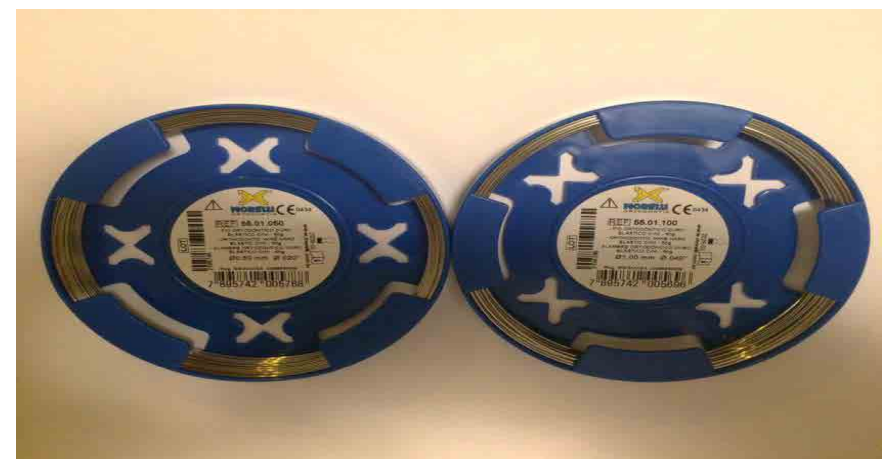

Figure 1. Metal wires used for analyses.

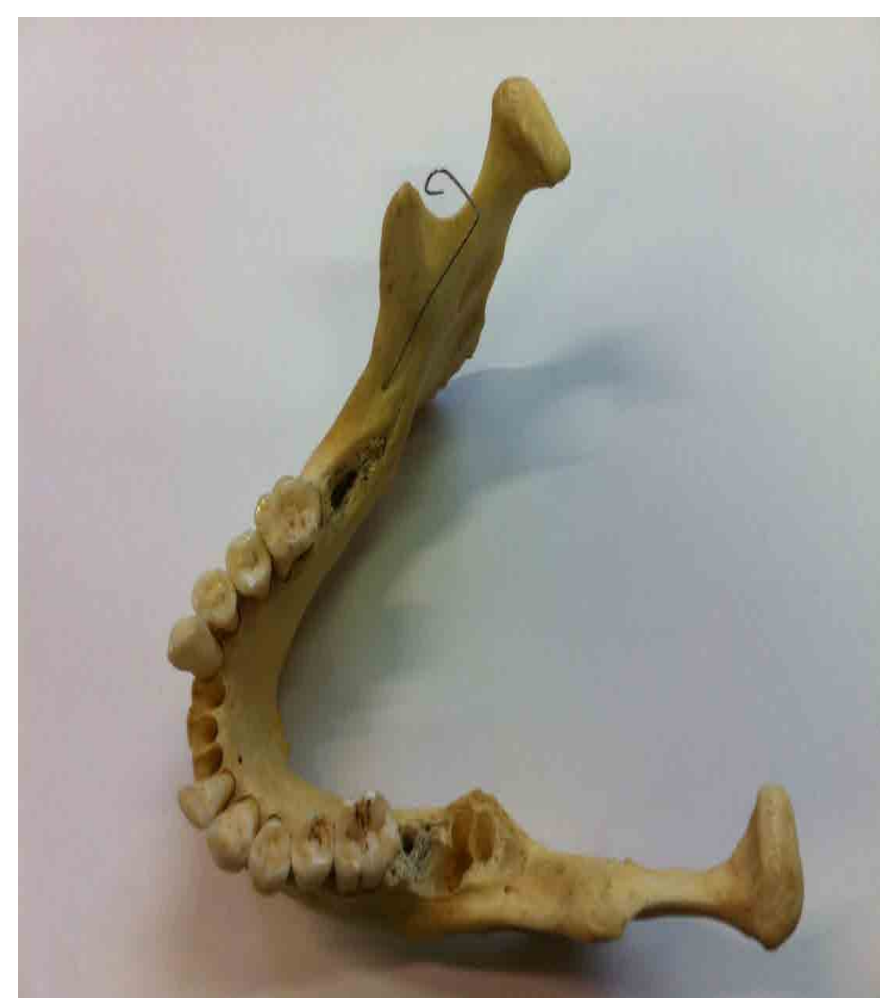

Figure 2. Example of macerated mandible presenting retromolar foramen with diameter between 0.5 and $1 \mathrm{~mm}$. 


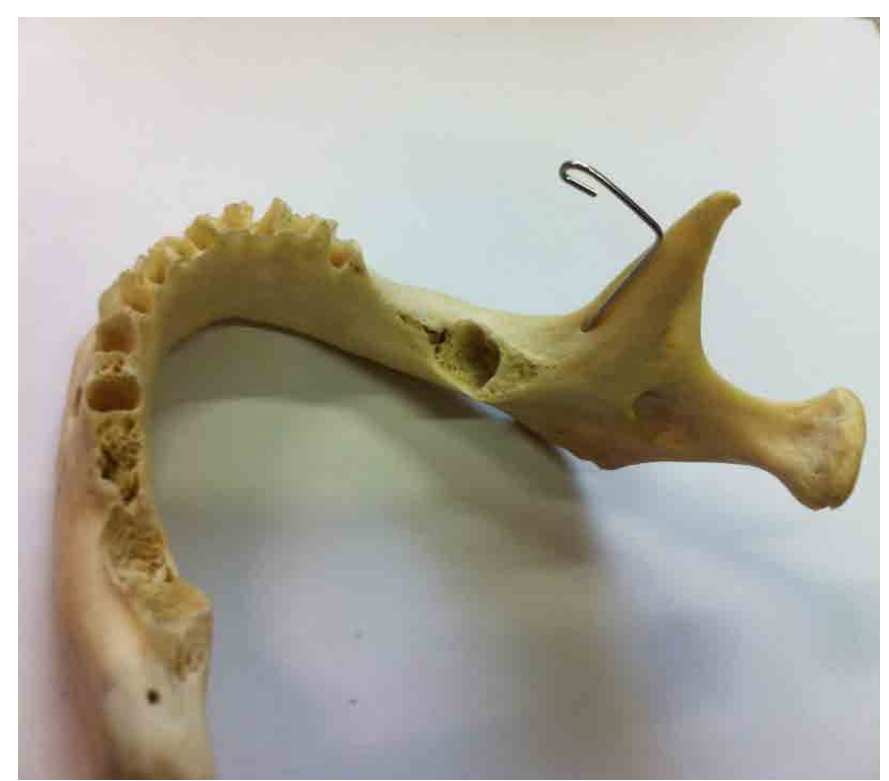

Figure 3. Example of macerated mandible presenting retromolar foramen with diameter larger than $1 \mathrm{~mm}$.

\section{Statistical analysis and ethical aspects}

Descriptive statistics were used for analyzing and presenting the data.

This study was approved by the Research Ethics Committee of the Federal University of São Paulo (Protocol 62066216.4.0000.5505).

\section{RESULTS}

\section{General}

Among the 265 mandibles, 62 presented RFs (23.4\%). Additional data relative to the RFs observed are summarized in Table 1.

Table 1. Retromolar foramina observed in the mandibles evaluated.

\begin{tabular}{lc}
\hline & Retromolar foramina \\
\hline Total & 103 \\
Mean & 0.4 \\
Standard Deviation & \pm 0.8 \\
Median & 0 \\
Minimum & 0 \\
Maximum & 4 \\
Total Amplitude & 4 \\
\hline
\end{tabular}

\section{Antimeres}

Data of the incidence of RFs in each antimere is summarized in Figure 4.

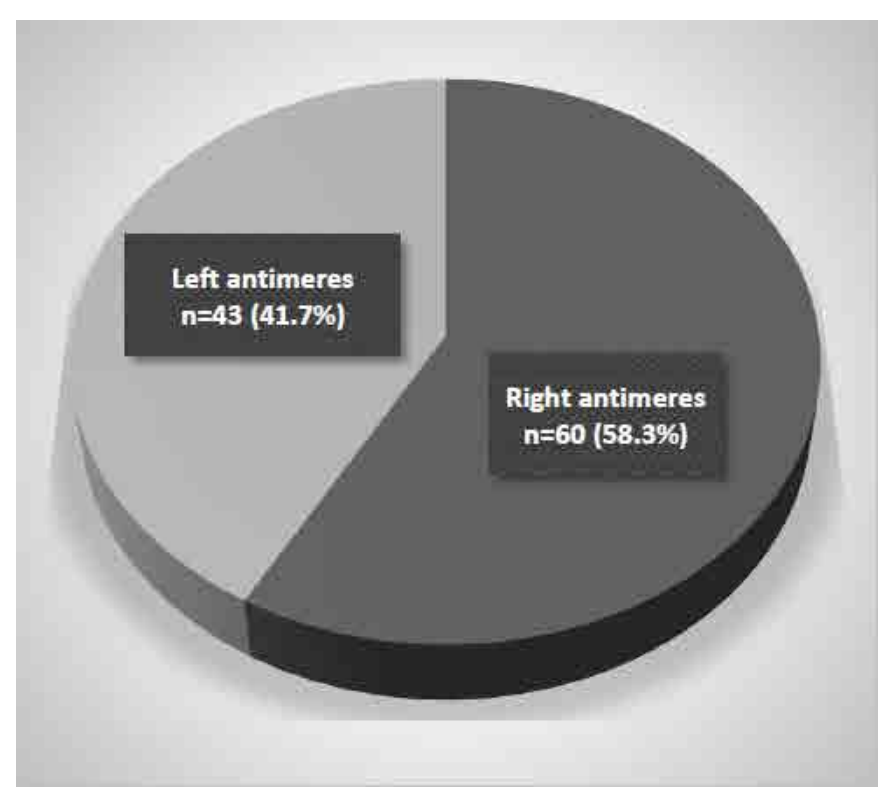

Figure 4. Frequency of retromolar foramina only in relation to antimeres.

Relative to disposition, 28 mandibles presented RFs bilaterally (10.6\%) and 34 unilaterally (12.8\%). Of the anatomic parts with RFs in a unilateral arrangement, 23 had RFs in the right (8.7\%), and 11 in the left (4.2\%) antimere. Moreover, up to 3 RFs could be visualized simultaneously in one and the same antimere.

\section{Diameters}

The diameters of the RFs observed are summarized in Table 2.

Table 2. Diameters of retromolar foramina observed in the mandibles evaluated, according to the antimeres.

\begin{tabular}{lccc}
\hline & \multicolumn{3}{c}{ Foramina (number and percentage) } \\
& Right Antimere & Left Antimere & Total \\
\hline $0.5-1 \mathrm{~mm}$ & $47(45.6 \%)$ & $35(34 \%)$ & $82(79.6 \%)$ \\
$>1 \mathrm{~mm}$ & $13(12.6 \%)$ & $8(7.8 \%)$ & $21(20.4 \%)$ \\
Total & $60(58.3 \%)$ & $43(4.7 \%)$ & $103(100 \%)$ \\
\hline
\end{tabular}

\section{DISCUSSION}

Tomographic studies have sought to evaluate the morphologic and topographic aspects of RFs and/or CRs, 
and so have other studies by means of direct visualization in dry mandibles and cadavers. Case reports have also been found in the literature, histologically categorizing the neurovascular structures passing through them.

In addition to RCs being erroneously considered a subtype of bifid mandibular canals $[4,12]$, the evident lack of methodological standardization in relation to the number and ethnicity of the samples has made it extremely difficult to compare the existent studies with new data. An extremely important example is the minimum diameter adopted for considering and accounting of the structures. In the present study the RFs were classified relative to diameter, as proposed by other authors [1], and excluding those that presented dimensions smaller than $0.5 \mathrm{~mm}$ [9]. On the other hand, a tomographic study considered RFs only with diameters larger than $1 \mathrm{~mm}$ [8].

Without methodological distinction, and considering RFs and RCs, the absolute frequency was demonstrated as follows: 65\% [13]; 52\% [4]; 26.7\% [11]; $26.58 \%$ [2]; 25.6\% [7]; 25\% [6]; 21.9\% [1]; $18.6 \%$ [5]; $16 \%[8] ; 11.7 \%$ [3]; $8.8 \%$ [14], and $8.5 \%$ [9]. Our finding $(23.4 \%)$ fits in satisfactorily in an intermediate position.

When considering the antimeres only, higher prevalence of these retromolar structures has been reported in a unilateral disposition either on the right $[1,5,9,14]$ or left side $[2,6]$. These facts are not in agreement with those here indicated, suggesting a higher bilateral prevalence. Other authors have, however, reported bilateral disposition being as frequent as unilateral on the right side [7].

Relative to the diameters of the retromolar structures, no study with similar methodology was found. Narayana et al. [1] characterized the RFs according to diameter (smaller than $0.5 \mathrm{~mm}$ and equal to or larger than $0.5 \mathrm{~mm}$ ) and noted great heterogeneity in the frequencies, in spite of foramina smaller than $0.5 \mathrm{~mm}$ being more common. Whereas, the data here obtained showed that the large majority of RFs presented diameters between 0.5 and $1 \mathrm{~mm}$.

Clinically, the relatively minute dimensions of the RFs and RCs are plausible explanations for the inability to visualize them in panoramic radiographs. Sisman et al. [11] identified RCs in cone beam computed tomographs and sought confirmation in panoramic radiographs, with an accuracy rate of $29 \%$. Using a similar manner, von Arx et al. [7] confirmed their presence in $22.6 \%$ of the cases. Other possible reasons for poor identification in panoramic radiographs are: irregular magnification, geometric distortion [14], superimposition of anatomic structures and ghost images [4]. In any event, these exams are used only for general and initial evaluation of the patient's stomatognathic complex [14]. When some condition that is outside the patterns of normality is suspected, or in cases of more complex surgeries, cone beam computed tomography must always be requested, as this provides images in three spatial dimensions, with relatively low doses of radiation and accessible values.

Another problem faced is determining the intraosseous communications of RCs. The majority of studies assume their own classifications, taking into consideration other anatomic structures in conjunction with the course of the canals, making it impossible to make direct comparisons among the data and draw definitive conclusions.

Equally, the information about structures passing through the RFs and CRs is obscure. Bilecenoglu \& Tuncer [6] performed a biopsy on the content of a patient's RC, and observed neurovascular bundles with striated muscle fibers, thin myelinized nerve fibers, numerous venules and a muscular artery with a lumen measuring from 120 to $130 \mu \mathrm{m}$. In spite of a great deal having been discussed about the eventual origins and terminals of the contents, it is evidence that they assume extreme clinical importance. It may be difficult to obtain anesthesia of the retromolar region, adjacent jugal mucosa or molar teeth [8], due to nerve bundles that escape the classical pterygomandibular block [1]. In invasive procedures in the region, such as the extraction of third molar teeth, mandibular sagittal osteotomies, or bone tissue collection for grafts [9], the RFs and RCs may be violated, resulting in excessive bleeding, temporary or permanent neurosensory disturbances [6], and even traumatic neuromas [12]. Moreover, they may also be a pathway of tumor propagation and infections, and even interfere in the placement of dental implants [8] and fabrication of dental prostheses [6].

\section{CONCLUSION}

According to the analyses made, RFs are consistent findings, since they were present in a considerable portion of the anatomic parts evaluated. Furthermore, as they generally have dimensions between 0.5 and $1 \mathrm{~mm}$, these structures are of notable clinical relevance and professionals must never underestimate them. This is because they may 
be potential causers of hemorrhages, anesthetic failures, important neurosensory disturbances, dissemination of tumors and infections, and even obstacles to implant placement and fabrication of dental prostheses.

\section{REFERENCES}

1. Narayana K, Nayak UA, Ahmed WN, Bhat JG, Devaiah BA. The retromolar foramen and canal in south indian dry mandibles. Eur J Anat. 2002;6(3):141-6.

2. Rossi AC, Freire AR, Prado GB, Prado FB, Botacin PR, Caria PHF. Incidence of retromolar foramen in human mandibles: ethnic and clinical aspects. Int J Morphol. 2012;30:1074-8.

3. Potu BK, Kumar V, Salem AH, Abu-Hijleh M. Occurrence of the retromolar foramen in dry mandibles of South-eastern part of India: a morphological study with review of the literature. Anat Res Int. 2014;2014:296717. doi: 10.1155/2014/296717

4. Kawai T, Asaumi R, Sato I, Kumazawa Y, Yosue T. Observation of the retromolar foramen and canal of the mandible: a CBCT and macroscopic study. Oral Radiol. 2012;28:10-14. doi: 10.1007/ s11282-011-0074-9

5. Alves N, Deana NF. Anatomical and radiographical study of the retromolar canal and retromolar foramen in macerated mandibles. Int J Clin Exp Med. 2015;8(3):4292-6.

6. Bilecenoglu B, Tuncer N. Clinical and anatomical study of retromolar foramen and canal. J Oral Maxillofac Surg. 2006 Oct;64(10):1493-7. doi: 10.1016/j.joms.2006.05.043

7. von Arx T, Hänni A, Sendi P, Buser D, Bornstein MM. Radiographic study of the mandibular retromolar canal: an anatomic structure with clinical importance. J Endod. 2011 Dec;37(12):1630-5. doi: 10.1016/j.joen.2011.09.007

8. Lizio G, Pelliccioni GA, Ghigi G, Fanelli A, Marchetti C. Radiographic assessment of the mandibular retromolar canal

\section{Collaborators}

The authors participated in all stages of preparation as article.

using cone-beam computed tomography. Acta Odontol Scand. 2013;71(3-4):650-5. doi: 10.3109/00016357.2012.704393

9. Han SS, Hwang YS. Cone beam CT findings of retromolar canals in a Korean population. Surg Radiol Anat. 2014 Nov;36(9):8716. doi: 10.1007/s00276-014-1262-1

10. Kumar Potu B, Jagadeesan S, Bhat KM, Rao Sirasanagandla S. Retromolar foramen and canal: a comprehensive review on its anatomy and clinical applications. Morphologie. 2013 Jun;97(317):31-7. doi: 10.1016/j.morpho.2013.04.004

11. Sisman $Y$, Ercan-Sekerci $A$, Payveren-Arikan $M$, Sahman $H$ Diagnostic accuracy of cone-beam CT compared with panoramic images in predicting retromolar canal during extraction of impacted mandibular third molars. Med Oral Patol Oral Cir Bucal. 2015 Jan 1;20(1):e74-81. doi: 10.4317/medoral.19930

12. Han SS, Park CS. Cone beam CT findings of retromolar canals: report of cases and literature review. Imaging Sci Dent. 2013 Dec;43(4):309-12. doi: 10.5624/isd.2013.43.4.309

13. Patil S, Matsuda Y, Nakajima K, Araki K, Okano T. Retromolar canals as observed on cone-beam computed tomography: their incidence, course, and characteristics. Oral Surg Oral Med Oral Pathol Oral Radiol. 2013 May;115(5):692-9. doi: 10.1016/j. 0ooo.2013.02.012

14. Capote TS, Gonçalves Mde A, Campos JA. Retromolar canal associated with age, side, sex, bifid mandibular canal, and accessory mental foramen in panoramic radiographs of Brazilians. Anat Res Int. 2015;2015:434083. doi: 10.1155/2015/434083

Received on: 10/7/2017 Final version resubmitted on: 8/8/2017 Approved on: 28/11/2017 